\title{
The occurrence of alien species in the settlement areas of the Kampinos National Park and its vicinity (Central Poland)
}

\author{
Izabella Kirpluk $^{1 *} \&$ Anna Bomanowska ${ }^{2}$
}

${ }^{1}$ Botanic Garden, Faculty of Biology, University of Warsaw, Aleje Ujazdowskie 4, 00-478 Warszawa, Poland ${ }^{2}$ Department of Geobotany and Plant Ecology, Faculty of Biology and Environmental Protection, University of Łódź, Banacha 12/16, 90-237 Łódź, Poland

* corresponding author (e-mail: ikirpluk@biol.uw.edu.pl)

\begin{abstract}
Studies aimed at the identification of the range and method of spread of alien plant species in settlement areas in Kampinos National Park (KNP) and its immediate vicinity were carried out in years 2012-2014. Special emphasis was put on surveying the sites of invasive alien species (IAS), and diagnosing potential threats posed to the natural and semi-natural vegetation of the national park by the IAS present in rural areas. We found 53 alien vascular plant species, including 40 invasive taxa which may potentially pose a threat to the ecosystems of KNP. Species encroaching from settlement areas to semi-natural and natural communities included: Bidens frondosa, Echinocystis lobata, Impatiens glandulifera, I. parviflora, Juncus tenuis, Lupinus polyphyllus, Reunoutria japonica and Solidago gigantea. Most of them were species from the highest invasiveness (IV and III) classes in Poland. Similarity analysis carried out for all investigated localities with regard to all alien species, and only for invasive ones showed a clear division into separate groups: villages within the boundaries of the national park and villages outside the park.
\end{abstract}

Key words: synanthropic habitats, protected area, invasive plants, rural areas

\section{Introduction}

Presence of alien plant species in a specific area is largely attributed to direct or indirect human activity. This particularly concerns kenophytes, which are alien species introduced in Poland after the $15^{\text {th }}$ century and now permanently established in habitats (Kornaś 1981; Sudnik-Wójcikowska \& Koźniewska 1988; TokarskaGuzik 2005). This group of plants includes taxa characterised by strong expansive potentials, easy colonization of new areas, and encroachment from anthropogenic habitats to semi-natural or natural habitats. This group also includes invasive alien species (IAS) that pose a threat to biological diversity by causing permanent changes in ecosystems (e.g. Richardson et al. 2000; Pyšek et al. 2004; Tokarska-Guzik 2005; TokarskaGuzik et al. 2009, 2012; Woziwoda 2012) .

KNP, like other protected areas in Poland or in other countries (e.g. De Poorter et al. 2007; Najberek \& Solarz
2011; Solarz 2012; Foxcroft et al. 2013), is not free from alien species. In particular, anthropogenic habitats in KNP are characterised by a considerable number of well-established alien species (Ferchmin 1979; Kirpluk 1996, 1998, 2003, 2009a, 2009b, 2012; Bomanowska 2006a, 2006b, 2009; Otręba 2008; Bomanowska et al. 2014a, 2014b). The encroachment and spreading of alien species in Kampinos Forest was facilitated by early development of settlements, then forest management (deliberate introduction of certain trees and shrubs) and, currently, tourism and development of residential areas on the periphery of KNP.

Buyouts of buildings and agricultural land in villages in KNP has been carried out since mid-1970s. Some former settlements located in KNP are partly or completely abandoned and actions to accelerate restoration of natural environment are being carried out in depopulated areas (Markowski 2009a, 2009b). Because the effects of everyday human activity only recently 
ceased in these habitats, the problem of alien species in this area still persists and remains unresolved. This, particularly, concerns invasive alien species.

The objective of the study was to present the floristic composition of alien plant species (with particular emphasis on IAS) occurring in settlement areas located within the limits of KNP and its immediate vicinity, and to identify their spread and potential threats posed by them to the natural and semi-natural vegetation of KNP.

\section{Material and methods}

Detailed floristic studies on the alien vascular flora of the rural areas were carried out between 2012 and 2014. They covered most of the settlement areas of Kampinos Forest, i.e. 118 villages of various size: 33 villages within the limits of KNP - populated, either partialy or completely depopulated, and 85 villages in the immediate vicinity of KNP, in its buffer zone, frequently near the border of KNP. A site was defined as a single village where a specific species was recorded. The location of plant sites was described by coordinates displayed by a GPS device (see Appendix 1).

In the study, we analysed alien species (anthropophytes) established in the flora of Poland, i.e. archaeophytes and kenophytes, according to the geographicalhistorical classification of flora proposed by Kornaś (1981).

Based on the floristic data derived from field studies, a complete list of alien species occurring in the settlement areas was prepared (Appendices 2-3). We considered those species that currently pose a threat to the natural and semi-natural ecosystems of KNP, and those that, because of their common occurrence in the settlement areas of the park and their uncontrolled growth, may pose such a threat in future. For this reason, we also listed common and expansively growing shrubs and trees which are tolerant of various habitat conditions in KNP but are not considered to be invasive in Poland (Tokarska-Guzik et al. 2012). In our list, we included species fulfilling the following criteria:

- invasive species in Poland according to the Regulation of the Minister of the Environment of the $9^{\text {th }}$ September 2011 on the list of alien plant and animal species which, when introduced into the natural environment, pose a threat to native biodiversity or natural habitats (Regulation 2011),

- species listed as "invasive alien species in Poland (Tokarska-Guzik et al. 2012), regardless of the occurrence of the taxon in KNP,

- species listed as "invasive alien species on a regional scale" (Tokarska-Guzik et al. 2012), if the acreage of a specific species is increasing, posing a threat to the natural environment of KNP,
- species spontaneously encroaching from cultivation and settled on synanthropic habitats in KNP (Kirpluk 2012).

Similarity of alien flora in individual villages was determined using cluster analysis (a single linkage method based on Euclidean distance; van Emden 2008).

Classes of invasiveness were presented according to Tokarska-Guzik et al. (2012). Plant names were adopted from Mirek et al. (2002).

\section{Results}

During the studies in the settlement areas in KNP, we identified 53 alien plant species, including 40 invasive taxa (Tokarska-Guzik et al. 2012) (Appendices 2-3). In individual sites (villages), we identified from 5 to 34 species. Considering the distribution of IAS alone, we recognized from 4 to 28 species. In the villages located within park boundaries, there were 6 to 28 invasive taxa, and 4 to 23 - in villages neighbouring the park. Most IAS (over 20) were recorded in the villages located within the limits of KNP: in 11 partly depopulated villages (Buda, Cisowe, Górki, Granica, Janówek, Józefów, Nowa Dąbrowa, Rybitew, Sieraków, Stara Dąbrowa), in one depopulated, completely abandoned village (Nowe Budy), and in 8 villages in the immediate vicinity of KNP (including as many as 6 villages near the park border: Kampinos, Korfowe, Lasocin, Lipków, Sadowa, Sowia Wola).

The most common tree and shrub species in all the analysed villages were: Rhus typhina (102 sites), Syringa vulgaris (97), Acer negundo (94), Robinia pseudoacacia (88), Parthenocissus inserta (71) and Rosa rugosa (60). The most common herbaceous species comprised: Conyza canadensis (103), Solidago gigantea (100), Setaria viridis (74), Solidago canadensis (71), Echinochloa crus-galli (70), Galinsoga parviflora (69), Helianthus tuberosus (68), Amaranthus retrofexus (67), Erigeron annuus (66), Anthoxanthum aristatum (62), Asparagus officinalis (61), Echinocystis lobata (60) and Rudbeckia laciniata (60). In the second group, field weeds formed a large grouping, persisted only on anthropogenic habitats and posed no serious threat to the natural ecosystems of KNP (Bomanowska et al. 2014a, 2014b). The only exception was Anthoxanthum aristatum, which was encroaching to psammophilous grasslands covered gradually by pine trees in the village of Bromierzyk, in the south-western part of KNP (authors' personal observations).

Considering the distribution of invasive species alone (Tokarska-Guzik et al. 2012), the most common species found within the park limits (Appendix 3) were: Amaranthus retroflexus (32 sites), Conyza canadensis (32), Echinochloa crus-galli (32), Galinsoga parviflora (30), Anthoxanthum aristatum (29), Oxalis fontana (29), 
single linkage method

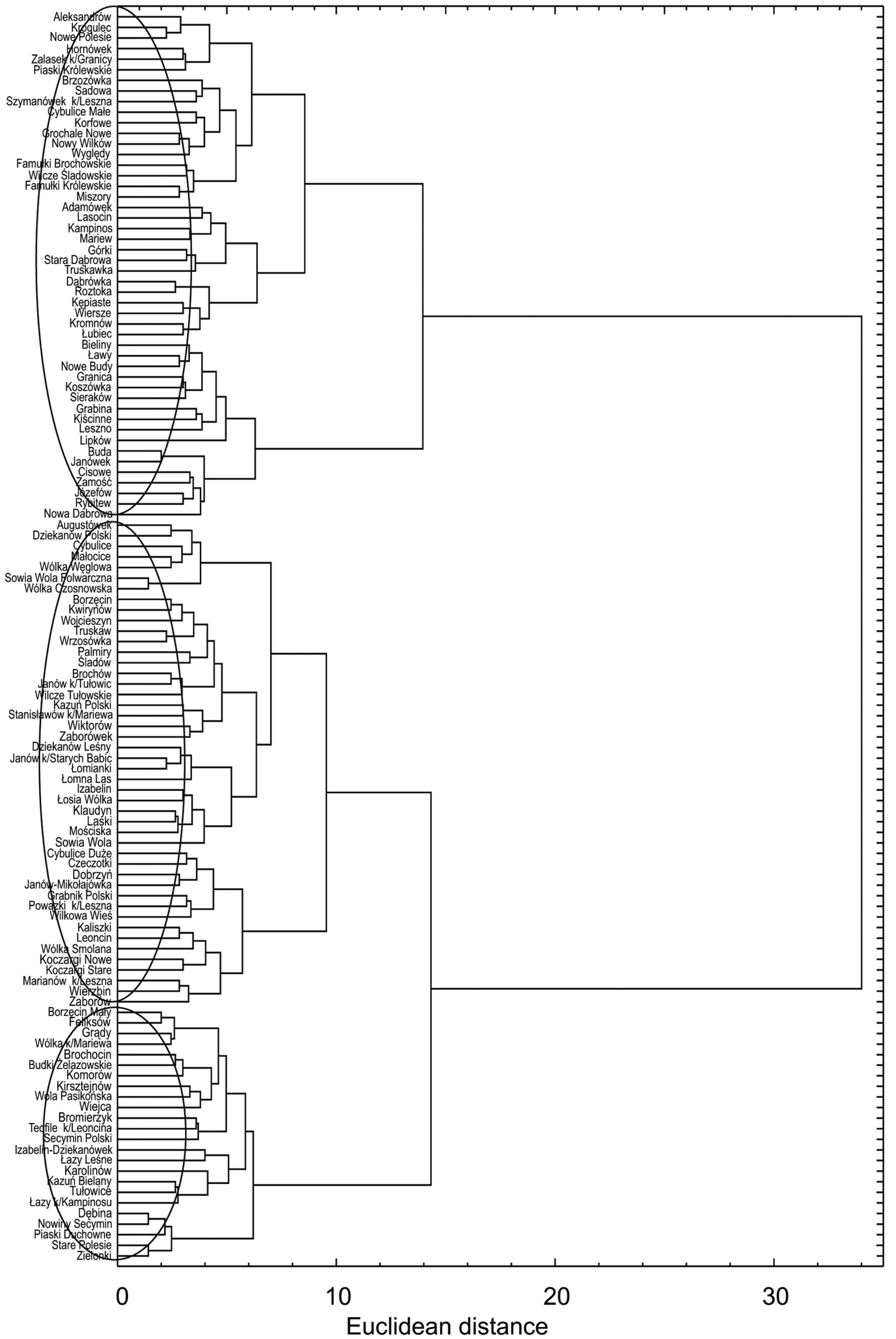

Fig. 1. Similarity of alien floras in the Kampinos villages (Euclidean distance) 
Setaria viridis (29), Robinia pseudoacacia (28), Setaria pumila (27), Solidago gigantea (24), Galinsoga ciliata (23), Rhus typhina (22), Veronica persica (22), Helianthus tuberosus (21), Rudbeckia laciniata (21) and Acer negundo (18). These taxa were recorded in over $50 \%$ of the villages located within KNP. Remarkably, the most common invasive plants were field weeds, posing no threat to the natural ecosystems of KNP. However, in sites located within the park boundaries (Appendices 2-3) as many as 17 taxa out of 37 IAS, were those of the highest invasiveness (class IV or III). In the analysed villages located within the limits of KNP, we found

single linkage method

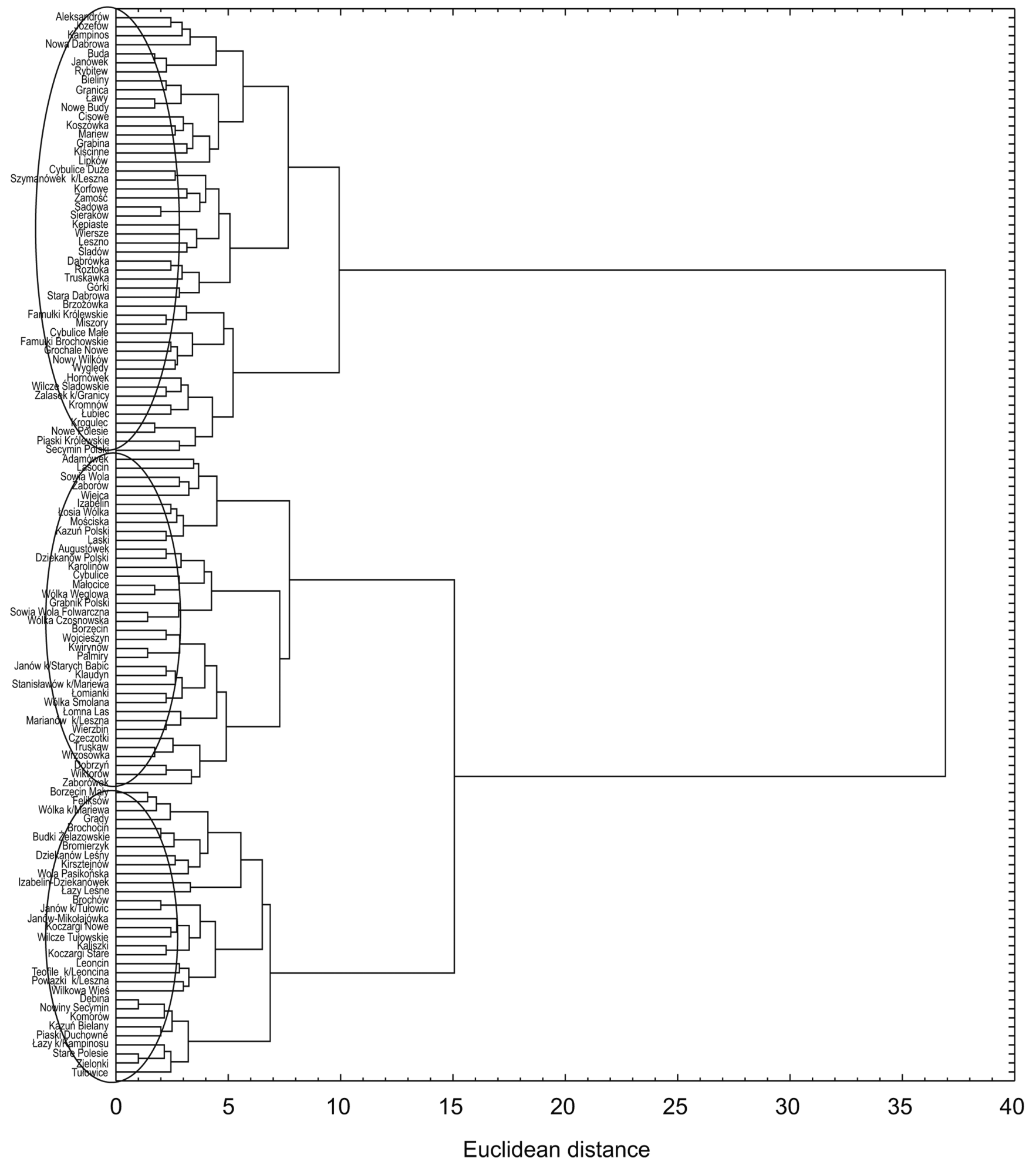

Fig. 2. Similarity of invasive alien floras in the Kampinos villages (Euclidean distance) 
no Asclepias syriaca, Padus serotina or Reynoutria sachalinensis.

In villages located in the immediate vicinity of KNP (Appendix 3), the most common invasive plant species included (number of sites in brackets): Rhus typhina (80), Acer negundo (76), Solidago gigantea (76), Conyza canadensis (60), Robinia pseudoacacia (60), Solidago canadensis (57), Parthenocissus inserta (57), Erigeron annuus (48), Helianthus tuberosus (47), Echinocystis lobata (45), Setaria viridis (45), and Rosa rugosa (44). This group comprised mostly perennial species, including numerous trees and shrubs. Some of these taxa were shown to be very expansive in Polish forests (Żukowski et al. 1995; Tokarska-Guzik 2005; Otręba \& Ferchmin 2007; Otręba 2008). In the villages outside KNP, as in villages within its limits, we found 17 taxa of the highest, i.e. class IV of invasiveness, except species such as Heracleum sosnowskyi and Bromus carinatus. There were also villages where we recorded presence of Padus serotina (16) and Reynoutria sachalinensis (3).

Similarity (cluster) analysis and classification conducted for the investigated localities with regard to all alien species, and for only IAS always led to the identification of two groups of objects: the first one was composed of villages within the park, the other one - of villages located in the protection zone. Villages located in KNP were floristically similar to each other and formed a separate group (Figs. 1-2). In these villages, more alien and invasive species occurred than in villages located outside the park (Appendices 2-3). Some of the analysed species (e.g. Bromus carinatus and Physalis alkekengi) emerged only in villages within the park. In both dendrograms, the only exceptions were three settlements inside KNP: Bromierzyk, Karolinów and Łazy Leśne. These villages were located peripherally, were difficult to access (especially Karolinów), and were partly or completely depopulated. Floristically, they were very similar to each other, but very different from the remaining villages of Kampinos Forest (Figs. 1-2). There were fewer species in them than in other villages inside the park. Villages located in the buffer zone of the park formed another group which, in both cases, could be floristically differentiated into two subgroups (Figs. 1-2). One subgroup (more numerous) comprised villages richer in alien an invasive species, whereas the other (less numerous) included floristically poorer ones (Appendix 3). Villages located near the border of KNP (e.g. Kampinos, Mariew, Lipków, Szymanówek near Leszno, Korfowe, Miszory) were more similar to villages located in KNP (Figs. 1-2). The group of villages outside the park was characterized by the occurrence of species such as: Asclepias syriaca, Padus serotina and Reynoutria sachalinensis (Appendix 3).

\section{Discussion}

The spreading and numerous sites of invasive taxa in park villages pose a serious threat to KNP ecosystems. Villages of Kampinos Forest, although located deep inside KNP and separated from each other by large patches of meadows and forest, were connected by numerous routes. Such conditions facilitated the dispersion of diaspores not only into neighbouring areas, but also for long distances, resulting in the colonization of new areas by invasive species (Adamowski et al. 2002; McKinney 2002; Pauchard \& Alaback 2004; Otręba 2008; Foxcroft et al. 2013). Results from our study indicate that the natural environment of KNP is also exposed to serious external threats. From 85 analysed villages located in the immediate vicinity of KNP, numerous invasive species can easily migrate to different semi-natural and natural communities of the park, e.g. Bidens frondosa, Echinocystis lobata, Impatiens glandulifera, I.parviflora, Juncus tenuis, Lupinus polyphyllus, Reynoutria japonica, Reynoutria sachalinensis and Solidago gigantea (Otręba 2008; Bomanowska et al. 2014b; authors' personal observations). Additionally, strong tourism and increasing urbanisation pressures can be observed to occur in KNP peripheries. All these factors facilitate spreading of alien species, including numerous IAS (Otręba 2008; authors' personal observations).

The performed studies demonstrated that among alien species growing in rural settlements, those classified as the most invasive vascular plants in Poland (Regulation 2011; Tokarska-Guzik et al. 2012) can also be found. These include: Acer negundo, Asclepias syriaca, Bromus carinatus, Echinocystis lobata, Heracleum sosnowskyi, Impatiens glandulifera, I. parviflora, Padus serotina, Reynoutria japonica, $R$. sachalinensis, Robinia pseudoacacia, Solidago canadensis, S. gigantea and Xanthium albinum.

Unfortunately, since the middle of the 1990s, when the first floristic studies were carried out on the synanthropic habitats of KNP (e.g. Bomanowska 2006a, 2006b, 2009; Kirpluk 1996, 1998, 2003, 2009), the number of sites of invasive species has increased considerably. There are villages in KNP (e.g. Górki, Famułki Królewskie) and its buffer zone (e.g. Adamówek, Łomianki), where Reynoutria japonica, one of the most expansive taxa, has already formed enormous 'monocultures' (Kotowska 2003), and its range is increasing year by year (authors' personal observations).

The most infested village was Górki, located in the very centre of KNP, very well connected by a road network and nearby canals with other villages inside and outside KNP. In Górki, we recorded the highest number of alien species (34), the highest number of invasive species (28), and all taxa of the highest invasiveness 
class (Appendices 2-3). It can be concluded that Górki is the central point for the distribution of alien and invasive taxa in KNP, but also the centre from which these plants are spreading. Górki is a village dating back to the mid- $18^{\text {th }}$ century, when the first settlements of tar makers were established in Kampinos (Kębłowska 2009). This is probably the site from where, in the early $20^{\text {th }}$ century, alien species could have spread to other villages in the park (e.g. to Cisowe, Granica, Nowe Budy, Nowa Dąbrowa, Zamość and Józefów), and then outside the boundaries of KNP (e.g. to the Kampinos villages). However, the initial plant migration pathways in the area of Kampinos Primeval Forest are unknown. The first alien species found in this area were reported by Kobendza (1930), but conclusive information on the introduction of alien species to KNP dates back only to the 1950s (Nowak 1983; Otręba 2008; Bomanowska et al. 2014a, 2014b).

Short distance to Warsaw conurbation (SudnikWójcikowska 1987), and the developed road network around KNP has certainly affected the number of alien species recorded in the analysed area. Developed lands neighbouring the park were also, and probably still are, a source from where alien plants dispersed to the protected area.

However, it seems that most alien species, including highly invasive taxa, escaped from intentional cultivation in cottage gardens in the analysed villages, although, as stated in Art. 120 clause 1 of the Nature Conservation Act of 16 April 2004 (Regulation 2009), "it is forbidden to introduce and import alien plant species to the natural environment".
Plants that escape from cultivation go through subsequent stages of establishment, and gain the status of epoecophyte or agriophyte (Kirpluk 2012). Some of the surveyed species (Appendix 3), not considered invasive in Poland (Tokarska-Guzik et al. 2012), are widely distributed in the park area, regardless of the conditions in which they currently grow. In partly or completely abandoned villages of Kampinos Forest, where the process of secondary succession is in progress, we simultaneously observe strong expansion of species such as Symphoricarpos albus, Syringa vulgaris and Philadelphus coronarius. Some taxa, e.g. Caragana arborescens, are more light-demanding (Zarzycki et al. 2002), but the encroachment of Sarothamnus scoparius from well-lit forest roadsides to forest clearings in KNP was also observed (authors' personal observations).

Not all the recorded alien species (Appendix 3) that now disperse seeds spontaneously and are found in anthropogenic and semi-natural habitats of the park will reach the status of invasive plants in the future. Nevertheless, they form a persistent, and most certainly anthropogenic, element of flora in these areas.

Acknowledgments. The authors are grateful to Dr. Hanna Werblan-Jakubiec, Head of the Botanic Garden, University of Warsaw, for financial support of field research and translation of the manuscript into English and Mr Włodzimierz Winiarski for his help in field research. We also thank an anonymous reviewer for his/her valuable suggestions and remarks concerning the paper.

\section{References}

Adamowski W., Dvorak L. \& Ramanjuk I. 2002. Atlas of alien woody species of the Białowieża Primaeval Forest, Phytocoenosis (N.S.) 14. Suppl. Cartogr. Geobot. 14: 1-303.

BOMANOWSKA A. 2006a. Importance of segetal habitat preservation for the biodiversity of Kampinos National Park. Pol. Bot. Stud. 22: 45-52.

BomanowsKa A. 2006b. Wybrane cechy flory segetalnej Kampinoskiego Parku Narodowego. Pam. Puławski 143: 27-35.

Bomanowska A. 2009. Rośliny towarzyszące uprawom - flora segetalna Puszczy Kampinoskiej. In: D. Michalska-Hejduk \& A. Bomanowska (eds.). Rola Kampinoskiego Parku Narodowego w zachowaniu różnorodności biologicznej dawnych terenów wiejskich, pp. 55-67. Kampinoski Park Narodowy, Izabelin.
Bomanowska A., Kirpluk I., Adamowski W., Palus J. \& OtręBA A. 2014a. Problem inwazji roślin obcego pochodzenia w polskich parkach narodowych. In: A. OtręBA \& D. Michalska-Hejduk (eds.). Inwazyjne gatunki roślin w Kampinoskim Parku Narodowym i w jego sąsiedztwie, pp. 9-14. Kampinoski Park Narodowy, Izabelin.

Bomanowska A., Ferchmin M., Kirpluk I. \& Otręba A. 2014b. Inwazyjne gatunki roślin we florze Puszczy Kampinoskiej. In: A. OtręBA \& D. Michalska-HejduK (eds.). Inwazyjne gatunki roślin w Kampinoskim Parku Narodowym i w jego sąsiedztwie, pp. 25-35. Kampinoski Park Narodowy, Izabelin.

De Poorter M., Pagad S. \& Ullah I. M. 2007. Invasive alien species and protected areas a scoping report. A scoping report. Part I. Scoping the scale and nature of invasive alien species threats to protected areas, impediments to 
IAS management and means to address those impediments. 94 pp. Prod. World Bank \& Global Invasive Species Programme (GISP).

FERCHMIN M. 1979. Rola drzew i krzewów w zbiorowiskach leśnych Puszczy Kampinoskiej. Rocznik Dendrologiczny 32: 53-67.

Foxcroft L. C., Pyšek P., Richardson D. M. \& Genovesi P. (eds.). 2013. Plant Invasions in Protected Areas: Patterns, Problems and Chellenges. Invading Nature - Springer Series in Invasion Ecology 7, pp. 656. DOI 10.1007/978-94-007-7750-7

KębŁowska A. 2009. Historia osadnictwa. In: D. MIChalska-Hejduk \& A. Bomanowska (eds.). Rola Kampinoskiego Parku Narodowego w zachowaniu różnorodności biologicznej i krajobrazowej dawnych obszarów wiejskich, pp. 9-21. Kampinoski Park Naroowy, Łódź-Izabelin.

KIRPLUK I. 1996. Structure of ruderal floras in abandoned villages in the Kampinos Forest. In: A. TeRPó \& S. MoCHNACKÝ (eds). II. Anthropization and environment of rural settlements. Flora and vegetation. Proc. of International Conference, pp. 124-133. Tarcal-Tokaj, Hungary.

KIRPLUK I. 1998. Anthropophytes of ruderal sites in several villages in the Kampinos Forest. In: S. MochnackÝ \& A. TERPó (eds.). III. Anthropization and environment of rural settlements. Flora and vegetation. Proc. of International Conference, pp. 153-160. Zemplińska Širava, Slovakia.

KIRPLUK I. 2003. Antropofity siedlisk ruderalnych wsi puszczańskich Kampinoskiego Parku Narodowego. In: R. Andrzejewski (ed.). Kampinoski Park Narodowy. Tom I. Przyroda Kampinoskiego Parku Narodowego, pp. 275-283. Kampinoski Park Narodowy, Izabelin.

KIRPLUK I. 2009a. Rośliny dawnych osad i przydroży - flora ruderalna. In: D. Michalska-Hejduk \& A. BomanowsKA (eds.). Rola Kampinoskiego Parku Narodowego W zachowaniu różnorodności biologicznej dawnych terenów wiejskich, pp. 67-77. Kampinoski Park Narodowy, Izabelin.

KIRPLUK I. 2009b. Gatunki dziczejące z upraw w opuszczanych wsiach Kampinoskiego Parku Narodowego. In: A. Andrzejewska \& A. Lubański (eds.). Trwałość i efektywność ochrony przyrody w polskich parkach narodowych, pp. 237-245. Kampinoski Park Narodowy, Izabelin.

KIRPLUK I. 2011. Najstarsi przybysze we florze ruderalnej opuszczanych wsi Kampinoskiego Parku Narodowego. Acta Botanica Silesiaca 7: 97-112.

KIRPLUK I. 2012. The most recent alien species of the ruderal flora in the abandoned villages of the Kampinos National Park (Central Poland). Thaiszia - J. Bot., Kosice 22(2): 143-153.

Kobendza R. 1930. Stosunki fitosocjologiczne Puszczy Kampinoskiej. Planta Pol. 2: 1-201.

KoRnAś J. 1981. Oddziaływanie człowieka na florę: mechanizmy i konsekwencje. Wiad. Bot. 25(3): 165-182.

Kotowska J. 2003. Zbiorowiska roślinne terenów wiejskich i gruntów porolnych. In: R. ANDRZEJEwSKI (ed.). Kampinoski Park Narodowy. Tom I. Przyroda Kampinoskiego Parku Narodowego, pp. 361-391. Kampinoski Park Narodowy, Izabelin.

Markowski M. 2009a. Użytkowanie terenów wiejskich dawniej i dziś. In: D. Michalska-Hejduk \& A. BoMANOwSKa (eds.). Rola Kampinoskiego Parku Narodowego $\mathrm{w}$ zachowaniu różnorodności biologicznej dawnych terenów wiejskich, pp. 21-30. Kampinoski Park Narodowy, Izabelin.

MarkowsKi M. 2009b. Wykupy gruntów i ich znaczenie dla ochrony przyrody. In: D. MichalskA-HeJduk \& A. BoMANOWSKA (eds.). Rola Kampinoskiego Parku Narodowego $\mathrm{w}$ zachowaniu różnorodności biologicznej dawnych terenów wiejskich, pp. 30-45. Kampinoski Park Narodowy, Izabelin.

McKinney M. L. 2002, Influence of settlement time, human population, park shape and age, visitation and roads on the number of alien plant species in protected areas in the USA, Diversity Distrib. 8: 311-318.

Mirek Z., Piękoś-Mirkowa H., Zając A. \& Zając M. 2002. Flowering plants and pteridophytes of Poland. A checklist. In: Z. MireK (ed.). Biodiversity of Poland, 1, 442 pp. W. Szafer Institute of Botany, Polish Academy of Sciences, Kraków.

NAJBereK K. \& Solarz W. 2011. Inwazje biologiczne w polskich parkach narodowych i krajobrazowych. In: Z. GŁowaciński, H. Okarma, J. PawŁowski \& W. SoLARZ (eds.). Księga gatunków obcych inwazyjnych w faunie Polski, pp. 624-639. Instytut Ochrony Przyrody, Kraków.

NowAK K. A. 1983. Flora strefy podmiejskiej Warszawy (na przykładzie byłego powiatu pruszkowskiego). Monogr. Bot. 64: 1-312.

OtrębA A. \& Ferchmin M. 2007. Obce gatunki drzew miara przekształcenia przyrody Kampinoskiego Parku Narodowego. Studia i Materiały CEPL w Rogowie 9(2/3) (16): 234-244.

OTRĘBA A. 2008. Rozprzestrzenianie się obcych inwazyjnych gatunków roślin jako realne zagrożenie przyrody Kampinoskiego Parku Narodowego. Dokumentacja Geograficzna 37: 194-204.

Pauchard A. \& Alaback P. B. 2004. Influence of elevation, land use, and landscape context on patterns of alien plant invasions along roadsides in protected areas of South-Central Chile. Conserv. Biology 18: 238-248.

Pyšek P., Richardson D. M., Rejmanek M., Webster G. L., Williamson M. \& Kirschner J. 2004. Alien plants in checklists and floras: towards better communication between taxonomists and ecologists. Taxon 53(1): 131-143.

Richardson D. M., Pyšek P., Rejmanek M., Barbour M. G., Panetta F. D. \& West C. J. 2000. Naturalization of alien plants: concepts and definitions. Diversity Distrib. 6: 93-107.

Solarz W. 2012. Przyczyny i skutki inwazji biologicznych na świecie i w Polsce. Studia i Materiały CEPL w Rogowie 4(33) (4): 9-14.

Sudnik-Wóscikowska B. 1987. Flora miasta Warszawy i jej przemiany w ciągu XIX i XX wieku. Part I [242 
pp.], part II [435 pp.]. Wyd. Uniw. Warszawskiego, Warszawa.

SudNik-WóJcikowska B. \& KoźNıEwsKa B. 1988. Słownik z zakresu synantropizacji szaty roślinnej. 93 pp. Wyd. Uniw. Warszawskiego, Warszawa.

Regulation 2009. The Nature Conservation Act of 16 April 2004. Journal of Laws Legal aspects of 2009 no. 151 item 1220, as amended.

Regulation 2011. The Regulation of the Minister of the Environment dated 9 September 2011. Journal of Laws of 2011, No. 210, item 1260.

TOKARSKA-GuZIK B. 2005. The Establishment and Spread of Alien Plant Species (Kenophytes) in the Flora of Poland. Prace naukowe Uniw. Śląskiego w Katowicach 2372: 1-192.

Tokarska-Guzik B., Bzdęga K., TarŁowska S. \& Koszela K. 2009. Gatunki z rodzaju rdestowiec Reynoutria spp. In: Z. DAJDOK \& P. PAWLACZyK (eds.). Inwazyjne gatunki roślin ekosystemów mokradłowych Polski, pp. 87-99. Wyd. Klubu Przyrodników, Świebodzin.
TokARsKa-GuZiK B., Dajdok Z., ZająC M., ZająC A., UrbisZ A., Danielewicz W. \& HoŁdyŃSKi C. 2012. Rośliny obcego pochodzenia w Polsce ze szczególnym uwzględnieniem gatunków inwazyjnych. 197 pp. GDOŚ, Warszawa.

Woziwoda B. 2012. Inwazje drzew introdukowanych w celach komercyjnych jako problem globalny. Studia i Materiały CEPL w Rogowie 4 (33) (4): 113-120.

VAN EMDEN H. 2008. Statistics for terrified biologists. xiii +343 pp. Blackwell Publishing, USA, UK, Australia.

ZARZYCKI K., TrZciŃSKa-TaciK H., RÓŻAŃSKi W., SZEląg Z., Wolek J. \& KorZeniak U. 2002. Ecological indicator values of vascular plants of Poland. In: Z. MireK (ed.). Biodiversity of Poland, 2, 183 pp. W. Szafer Institute of Botany, Polish Academy of Sciences, Kraków.

Żukowski W., Latowski K., JACKowiak B. \& Chmiel J. 1995. Rośliny Wielkopolskiego Parku Narodowego. Prace Zakładu Taksonomii Roślin UAM w Poznaniu 4: 1-231. Bogucki Wyd. Nauk., Poznań. 
Appendix 1. Names of studied localities with their coordinates

\author{
Aleksandrów 52,335510(N); 20,620441(E) \\ Adamówek 52,366352; 20,714308 \\ Augustówek 52,374184; 20,699465 \\ Bieliny 52,306778; 20,437246 \\ Borzęcin 52,247044; 20,708767 \\ Borzęcin Mały 52,247044; 20,708767 \\ Brochocin 52,305067; 20,304193 \\ Brochów 52,319180; 20,260780 \\ Bromierzyk 52,308979; 20,387550 \\ Brzozówka 52,348751; 20,659260 \\ Buda 52,294308; 20,741314 \\ Budki Żelazowskie 52,284721; 20,326666 \\ Cisowe 52,334747; 20,491268 \\ Cybulice 52,383106; 20,650299 \\ Cybulice Duże 52,376366; 20,629017 \\ Cybulice Małe 52,389435; 20,636955 \\ Czeczotki 52,383492; 20,658243 \\ Dąbrówka 52,35086; 20,601082 \\ Dębina 52,391846;20,714924 \\ Dobrzyń 52,373734; 20,718275 \\ Dziekanów Leśny 52,341309; 20,847546 \\ Dziekanów Polski 52,367538; 20,838736 \\ Famułki Brochowskie 52,309536; 20,352934 \\ Famułki Królewskie 52,335976; 20,370367 \\ Feliksów 52,236732; 20,316566 \\ Górki 52,324539; 20,519049 \\ Grabina 52,289730; 20,569298 \\ Grabnik Polski 52,278015; 20,415073 \\ Granica 52,286903; 20,446985 \\ Grądy 52,256020; 20,570793 \\ Grochale Nowe 52,402657; 20,591759 \\ Hornówek 52,287296;20,798208 \\ Izabelin 52,284641; 20,831585 \\ Izabelin-Dziekanówek 52,352584; 20,818534 \\ Janów k/Starych Babic 52,265709; 20,843559 \\ Janów k/Tułowic 52,328529; 20,271210 \\ Janów-Mikołajówka 52,368820; 20,640808 \\ Janówek 52,346401; 20,720144 \\ Józefów 52,283741; 20,475399 \\ Kaliszki 52,374107; 20,741743 \\ Kampinos 52,267658; 20,460804 \\ Karolinów 52,319151; 20,408588 \\ Kazuń Bielany 52,402645; 20,682795 \\ Kazuń Polski 52,402210; 20,653172 \\ Kępiaste 52,286121; 20,605740 \\ Kirsztajnów 52,283539; 20,335238 \\ Kiścinne 52,326180; 20,630388 \\ Klaudyn 52,279022; 20,853281 \\ Koczargi Nowe 52,259251; 20,795284 \\ Koczargi Stare 52,266197; 20,795797 \\ Komorów 52,269260; 20,427988 \\ Korfowe 52,271545; 20,516792 \\ Koszówka 52,275188; 20,476233 \\ Krogulec 52,322068; 20,640221 \\ Kromnów 52,375809; 20,336048 \\ Kwirynów 52,257381; 20,852139 \\ Laski 52,292946; 20,846939 \\ Lasocin 52,299625; 20,352921 \\ Leoncin 52,396908; 20,539021
}

Leszno 52,257568; 20,590775

Lipków 52,275242; 20,804586

Ławy 52,294182; 20,677057

Łazy k/Kampinosu 52,293362; 20,411327

Łazy Leśne 52,293056; 20,412222

Łomianki 52,343151; 20,875471

Łomna Las 52,$363611 ; 20,790833$

Łosia Wólka 52,365643; 20,696569

Łubiec 52,293365; 20,594057

Małocice 52,373165; 20,674913

Marianów k/Leszna 52,265255; 20,560850

Mariew 52,284367; 20,731709

Miszory 52,341080; 20,322094

Mościska 52,287765; 20,868162

Nowa Dąbrowa 52,331585; 20,587837

Nowe Budy 52,319942; 20,544243

Nowe Polesie 52,373520; 20,474466

Nowy Secymin 52,386116; 20,451443

Nowy Wilków 52,384148; 20,508036

Palmiry 52,365677; 20,777781

Piaski Duchowne 52,370686; 20,398722

Piaski Królewskie 52,366667; 20,416667

Powązki k/Leszna 52,264393; 20,532202

Roztoka 52,312279; 20,614618

Rybitew 52,384487; 20,592506

Sadowa 52,347820; 20,827181

Secymin Polski 52,380268; 20,428782

Sieraków 52,311543; 20,813267

Sowia Wola 52,362679; 20,649366

Sowia Wola Folwarczna 52,365677; 20,629375

Stanisławów k/Mariewa 52,280315; 20,743351

Stara Dabrowa 52,341808; 20,563940

Stare Polesie 52,368206; 20,457035

Szymanówek k/Leszna 52,273968; 20,551867

Śladów 52,374485; 20,309931

Truskaw 52,306389; 20,770176

Teofile k/Leoncina 52,388119; 20,526344

Truskawka 52,330261; 20,674761

Tułowice 52,336548; 20,281645

Wiejca 52,261246; 20,503529

Wierzbin 52,260567; 20,735813

Wiersze 52,$321285 ; 20,641640$

Wiktorów 52,265766; 20,703299

Wilcze Śladowskie 52,35472; 20,301649

Wilcze Tułowskie 52,349183; 20,302863

Wilkowa Wieś 52,259369; 20,525467

Wojcieszyn 52,256435; 20,766598

Wola Pasikońska 52,265427; 20,382853

Wólka k/Mariewa 52,280132; 20,711632

Wólka Czosnowska 52,376930; 20,652651

Wólka Smolana 52,289742; 20,311230

Wólka Węglowa 52,300015; 20,883229

Wrzosówka 52,371963; 20,660917

Wyględy 52,260204; 20,689787

Zaborów 52,261589; 20,675035

Zaborówek 52,262016; 20,625542

Zamość 52,316685; 20,489849

Zalasek k/Granicy 52,296355; 20,428219

Zielonki 52,243511; 20,830933 
Appendix 2. The number of alien species in individual villages

\begin{tabular}{|c|c|c|c|}
\hline Village & No. of species & Village & No. of species \\
\hline Aleksandrów (Al) & 22 & Leszno (Les) & 22 \\
\hline Adamówek (Ad) & 22 & Lipków (Li) & 27 \\
\hline Augustówek (Au) & 14 & Lawy (Law) & 23 \\
\hline Bieliny (Bi) & 23 & Łazy k/Kampinosu (LK) & 13 \\
\hline Borzęcin (Bo) & 18 & Lazy Leśne (LL) & 15 \\
\hline Borzęcin Mały (BM) & 10 & Łomianki (Lo) & 21 \\
\hline Brochocin $(\mathrm{Br})$ & 09 & Łomna Las (LoL) & 16 \\
\hline Brochów (Bro) & 16 & Łosia Wólka (LW) & 22 \\
\hline Bromierzyk (Brom) & 10 & Lubiec (Lu) & 19 \\
\hline Brzozówka (Brz) & 17 & Małocice (Ma) & 15 \\
\hline Buda (Bu) & 28 & Marianów k/Leszna (ML) & 18 \\
\hline Budki Żelazowskie (BZ) & 10 & Mariew (Mar) & 25 \\
\hline Cisowe (Ci) & 32 & Miszory (Mi) & 20 \\
\hline Cybulice (Cy) & 12 & Mościska (Mo) & 20 \\
\hline Cybulice Duże (CD) & 22 & Nowa Dąbrowa (ND) & 30 \\
\hline Cybulice Małe (CM) & 20 & Nowe Budy (NB) & 31 \\
\hline Czeczotki $(\mathrm{Cz})$ & 20 & Nowe Polesie (NP) & 16 \\
\hline Dąbrówka (Da) & 18 & Nowiny Secymin (NS) & 05 \\
\hline Dębina (De) & 07 & Nowy Wilków (NW) & 16 \\
\hline Dobrzyń (Do) & 15 & Palmiry $(\mathrm{Pa})$ & 19 \\
\hline Dziekanów Leśny (DL) & 14 & Piaski Duchowne (PD) & 10 \\
\hline Dziekanów Polski (DP) & 18 & Piaski Królewskie (PK) & 14 \\
\hline Famułki Brochowskie (FB) & 18 & Powązki k/Leszna (PL) & 18 \\
\hline Famułki Królewskie (FK) & 20 & Roztoka (Ro) & 19 \\
\hline Feliksów $(\mathrm{Fe})$ & 8 & Rybitew (Ry) & 30 \\
\hline Górki (Go) & 34 & Sadowa (Sa) & 25 \\
\hline Grabina (Gr) & 22 & Secymin Polski (SP) & 14 \\
\hline Grabnik Polski (GP) & 18 & Sieraków (Si) & 30 \\
\hline Granica (Gra) & 29 & Sowia Wola (SW) & 26 \\
\hline Grądy (Grad) & 12 & Sowia Wola Folwarczna (SWF) & 12 \\
\hline Grochale Nowe (GN) & 20 & Stanisławów k/Mariewa (SM) & 16 \\
\hline Hornówek (Ho) & 12 & Stara Dąbrowa (SD) & 26 \\
\hline Izabelin (Iz) & 23 & Stare Polesie (StP) & 5 \\
\hline Izabelin-Dziekanówek (ID) & 13 & Szymanówek k/Leszna (SL) & 20 \\
\hline Janów k/Starych Babic (JSB) & 16 & Śladów (S1) & 24 \\
\hline Janów k/Tułowic (JT) & 16 & Teofile k/Leoncina (TL) & 15 \\
\hline Janów-Mikołajówka (JM) & 15 & Truskaw (Tr) & 17 \\
\hline Janówek (Ja) & 30 & Truskawka (Tru) & 21 \\
\hline Józefów (Jo) & 31 & Tułowice $(\mathrm{Tu})$ & 12 \\
\hline Kaliszki (Ka) & 17 & Wiejca (Wi) & 16 \\
\hline Kampinos (Kam) & 24 & Wierzbin (Wie) & 18 \\
\hline Karolinów (Kar) & 18 & Wiersze (Wier) & 22 \\
\hline Kazuń Bielany (KB) & 11 & Wiktorów (Wik) & 21 \\
\hline Kazuń Polski (KP) & 21 & Wilcze Śladowskie (WS) & 14 \\
\hline Kępiaste (Ke) & 23 & Wilcze Tułowskie (WT) & 13 \\
\hline Kirsztajnów (Ki) & 10 & Wilkowa Wieś (WW) & 16 \\
\hline Kiścinne (Kis) & 23 & Wojcieszyn (Wo) & 15 \\
\hline Klaudyn (Kl) & 21 & Wola Pasikońska (WP) & 09 \\
\hline Koczargi Nowe (KN) & 12 & Wólka k/Mariewa (WM) & 12 \\
\hline Koczargi Stare (KS) & 15 & Wólka Czosnowska(WC) & 10 \\
\hline Komorów (Ko) & 13 & Wólka Smolana (WSm) & 22 \\
\hline Korfowe (Kor) & 21 & Wólka Węglowa (WWe) & 13 \\
\hline Koszówka (Kos) & 26 & Wrzosówka (Wr) & 16 \\
\hline Krogulec (Kr) & 19 & Wyględy (Wy) & 20 \\
\hline Kromnów (Kro) & 18 & Zaborów (Za) & 26 \\
\hline Kwirynów (Kw) & 14 & Zaborówek (Zab) & 26 \\
\hline Laski (La) & 20 & Zamość (Zam) & 31 \\
\hline Lasocin (Las) & 27 & Zalasek k/Granicy (ZG) & 15 \\
\hline Leoncin (Le) & 19 & Zielonki (Zi) & 05 \\
\hline
\end{tabular}


Appendix 3. The list of alien species occurring in the rural habitats in the Kampinos National Park and its closest vicinity

Explanations: the invasive species are underlined; the villages located within the borders of the Kampinos National Park are marked in bold; the abbreviations of village names - see Appendix 2

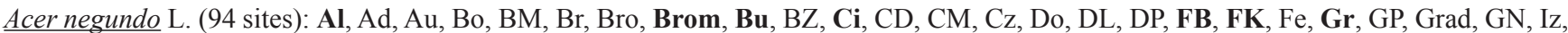
ID, JSB, JT, JM, Ja, Jo, Ka, Kam, Kar, KB, KP, Kis, K1, KN, KS, Ko, Kor, Kos, Kr, Kw, La, Las, Le, Les, Li, Law, LK, Lo, LoL, LW, Ma, ML, Mar, Mi, Mo, NB, NP, NW, Pa, PD, PL, Ry, Sa, Si, SW, SWF, SM, StP, Sl, TL, Tr, Tu, Wi, Wie, Wik, WT, WW, Wo, WP, WM, WC, WSm, WWe, Wr, Wy, Za, Zab, Zam, Zi. Aesculus hippocastanum L. (42): Bro, Bu, Ci, DL, Fe, Gr, Gra, Iz, JSB, Ja, Jo, Kam, Kar, KB, Kis, KN, Kos, Kr, Li, Law, LK, LL, Lo, Mar, ND, NB, Pa, PK, Ro, Ry, Si, SW, Sl, TL, Tu, Wie, Wo, WSm, Za, Zab, Zam, ZG. Amaranthus retroflexus L. (67): Al, Ad, Au, Bi, Brom, Brz, Bu, Ci, CD, CM, Da, Do, DP, FB, FK, Go, Gr, GP, Gra, GN, Ho, JSB, Ja, Jo, Kam, Kar, KP, Ke, Kis, Kl, Kor, Kos, Kr, Kro, Kw, La, Las, Le, Les, Li, Law, Lo, Lu, Mar, Mi, ND, NB, NP, Pa, PK, Ro, Ry, Sa, Si, SW, SM, SD, SL, Tru, Wier, Wik, WS, WM, Wy, Zab, Zam, ZG. Anthoxanthum aristatum Boiss. (62): Al, Ad, Bi, Br, Bro, Brz, Bu, BZ, Ci, CD, CM, Da, FB, FK, Go, Gra, GN, Ho, JT, Ja, Jo, Kam, Ke, Ki, Kis, Kl, KS, Ko, Kor, Kos, Kr, Kro, Las, Les, Law, LL, Lu, ML, Mar, Mi, ND, NB, NP, NW, PL, Ro, Ry, Sa, Si, SM, SD, SL, Tru, Wier, Wik, WS, WW, WSm, Wy, Zab, Zam, ZG. Asclepias syriaca L. (1): WP. Asparagus officinalis L. (61): Ad, Bi, Bo, Br, Bro, Bu, Ci, CD, Cz, Da, FB, FK, Go, GP, Gra, Iz, ID, JT, JM, Ja, Jo, Ka, Kar, KB, KP, Ke, Kis, KN, Kos, Kro, Le, Les, Li, Law, LK, Lu, Ma, ML, Mar, Mi, ND, NB, NW, Pa, Ro, Si, SM, SD, Sl, TL, Tr, Tu, Wie, Wier, WT, WW, WM, WSm, Za, Zab, Zam. Aster novi-belgii L. (35): Al, Ad, Au, Cy, Da, DP, Go, GP, Iz, Jo, KP, Ke, K1, Kr, Las, LL, LW, Lu, Ma, Mo, ND, Ro, Sa, Si, SW, SWF, SD, Tr, Tru, Wier, WW, WC, WWe, Wr, Zab. Avena fatua L. (18): Bu, GP, Ja, Ke, Kis, Kor, Las, Les, Lu, ND, NW, PL, SP, SL, TL, Wier, Zam, ZG. Avena strigosa Schreb. (17): Al, Bi, Brz, Ci, CD, Cz, Go, GP, Kam, Kis, Las, Lu, Mar, NB, PL, Ry, SP. Bidens frondosa L. (19): Al, Ad, Ci, Go, Gr, Iz, ID, Jo, Kam, Kis, Las, LL, LoL, Mar, ND, NB, Ry, SD, Tru. Bromus carinatus Hook. \& Arn. (1): Ry. Caragana arborescens Lam. (28): Bu, BZ, Ci, FB, FK, Gra, Ja, Jo, Ka, Kar, Ki, Ko, Kos, Kro, Le, Li, Law, LK, LW, Mi, NB, Pa, Si, SW, WS, WP, WSm, Zam. Conyza canadensis (L.) Cronquist (103): Al, Ad, Au, Bi, Bo, BM, Br, Bro, Brom, Brz, Bu, BZ, Ci, Cy, CD, CM, Cz, Da, Do, DL, DP, FB, FK, Go, Gr, GP, Gra, Grad, GN, Iz, ID, JSB, JT, JM, Ja, Jo, Ka, Kam, Kar, KP, Ke, Ki, Kis, Kl, Ko, Kor, Kos, Kr, Kro, Kw, La, Las, Le, Les, Li, Law, LL, Lo, LoL, LW, Lu, Ma, ML, Mar, Mi, Mo, ND, NB, NP, NW, Pa, PK, PL, Ro, Ry, Sa, SP, Si, SW, SWF, SM, SD, SL, Sl, TL, Tr, Tu, Wi, Wie, Wier, Wik, WS, WT, Wo, WM, WC, WSm, WWe, Wr, Za, Zab, Zam, ZG. Echinochloa crus-galli (L.) P. Beauv. (70): Al, Ad, Bi, Bo, Bro, Brom, Brz, Bu, Ci, CD, CM, Cz, Da, FB, FK, Go, Gr, Gra, GN, Ho, ID, JT, Ja, Jo, Kam, Ke, Kis, K1, Kor, Kos, Kr, Kro, Kw, Las, Li, Law, LL, Lu, ML, Mar, Mi, Mo, ND, NB, NP, NW, Pa, PK, Ro, Ry, Sa, SP, Si, SD, SL, Sl, Tr, Tru, Wi, Wie, Wier, Wik, WS, Wo, Wr, Wy, Za, Zab, Zam, ZG. Echinocystis lobata (F. Michx.) Torr. \& A. Gray (60): Al, Ad, Bo, Ci, Cy, CD, CM, Cz, Da, Do, FK, Go, GP, GN, Iz, ID, JSB, JM, Ja, Jo, Ka, Kam, KP, Kl, KN, KS, Kor, Kos, Kw, La, Le, Li, Lo, LW, Ma, Mar, ND, NW, PL, Ro, Ry, Sa, Si, SW, SWF, SL, Tru, Tu, Wi, Wier, Wik, WS, WW, Wo, WC, WSm, WWe, Wy, Za, Zam. Epilobium ciliatum Raf. (8): CD, CM, Go, Ho, Kor, Li, ND, SW. Erigeron annuus (L.) Pers. (66): Ad, Bi, Bo, BM, Brz, Bu, Ci, Cy, CD, Cz, Do, DL, DP, FK, Fe, Go, Gr, GP, Gra, Grad, Iz, JSB, JM, Ja, KP, Ke, Ki, Kl, Kor, Kos, Kw, La, Les, Li, Law, LK, LL, Lo, LoL, LW, Ma, Mar, Mi, Mo, ND, NB, Pa, Ry, Sa, Si, SW, SM, SD, Sl, Tr, Wi, Wie, Wik, WW, Wo, WP, WM, WSm, Wr, Za, Zab. Galinsoga ciliata (Raf.) S. F. Blake (35): Al, Bi, Brz, Bu, Ci, CD, CM, Da, Go, Gr, Gra, GN, Ja, Jo, Kam, Ke, Kis, Kos, Kro, Les, Li, Law, Lu, Mar, ND, NB, NP, Ro, Ry, Sa, Si, SD, SL, Sl, Zam. Galinsoga parviflora Cav. (69): Al, Ad, Au, Bi, Brz, Bu, Ci, Cy, CD, CM, Da, DP, FB, FK, Go, Gr, Gra, GN, Ho, JT, Ja, Jo, Kam, Kar, KP, Ke, Kis, Kl, Kor, Kos, Kr, Kro, La, Las, Les, Li, Law, LoL, LW, Lu, Ma, ML, Mar, Mi, Mo,

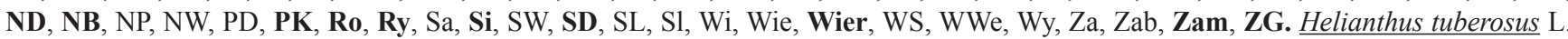
(68): Ad, Bi, Bo, Bro, Bu, CD, CM, Cz, Da, DP, FB, Go, Gr, Gra, GN, Ho, Iz, JSB, JT, JM, Ja, Jo, Ka, Kam, KP, Ke, Kl, KN, KS, Kr, Kro, Kw, La, Las, Le, Les, Li, LK, Lo, LoL, LW, Lu, Ma, ML, Mar, Mo, ND, Pa, Ro, Ry, Sa, Si, SW, SM, SD, Sl, Tr, Tru, Wie, Wier, WT, Wo, WSm, WWe, Wr, Za, Zam, ZG. Heracleum sosnowskyi Manden (1): Go. Impatiens glandulifera Royle (26): Brz, Bu, Ci, CD, Da, Go, Iz, ID, JM, Ja, KN, Las, LW, Mo, Pa, PL, Ry, Sa, SW, SD, SL, Tru, WT, WW, Za, Zam. Impatiens parviflora DC. (42): Ci, CD, CM, Cz, Do, DL, Go, Gr, Gra, Ho, Iz, ID, JSB, JM, Jo, KP, Ke, K1, KS, Kor, Kos, Las, Le, Li, LL, Lo, LoL, ML, Mar, Mo, PK, PL, Si, SD, SL, Tr, Wie, Wier, Wik, Za, Zab, Zam. Iva xanthiifolia Nutt. (8): Bo, DP, Ka, Li, ND, NB, WWe, Wy. Juncus tenuis Willd. (14): Al, Bu, Ci, Go, Ja, Jo, Kam, Kar, KS, Kos, ND, Ry, Zab, Zam. Leymus arenarius (L.) Hochst. (13): Brom, Bu, CM, FB, FK, Go, Ja, Jo, Las, ML, Ry, Si, Tru. Lolium multiflorum Lam. (7): Brz, Las, Li, Mi, ND, TL, Wi. Lupinus polyphyllus Lindl. (19): Ad, Bi, Bo, Bu, Ci, Gr, Grad, Ja, Jo, Kar, Li, Law, LL, LoL, Ma, NB, Ry, Wik, WP. Lycium barbarum L. (10): Bu, Ci, DL, Gr, Ki, Kis, Li, Tu, Za, Zab. Oxalis fontana Bunge (44): Al, Bi, Brz, Bu, Ci, CM, Da, FK, Go, Gr, Gra, GN, Ja, Jo, Kam, Ke, Kis, Kor, Kos, Kr, Kro, Les, Law, Lu, Mar, Mi, ND, NB, NP, NW, PK, Ro, Ry, Sa, SP, Si, SD, Sl, Tru, Wier, WS, Wy, Zam, ZG. Padus serotina (Ehrh.) Borkh. (16): Br, CM, Grad, Ka, KN, KS, Las, Le, Lo, LW, ML, SW, Wik, WSm, Wy, Za. Parthenocissus inserta (A. Kern.) Fritsch (71): Ad, Au, Bo, BM, Bro, BZ, Ci, Cy, CD, Cz, Do, DL, DP, Fe, Go, GP, Gra, Grad, Iz, JSB, JT, JM, Ja, Ka, Kam, Kar, KP, Ke, K1, KN, KS, Kw, La, Las, Law, Lo, LoL, LW, Lu, Ma, ML, Mar, Mo, NB, Pa, PL, Ro, Sa, Si, SW, SWF, SM, SD, SL, Sl, Tr, Tru, Wi, Wie, Wier, Wik, WT, Wo, WP, WM, WC, WSm, WWe, Wr, Za, Zab. Philadelphus coronarius L. (39): Bi, BM, Br, BZ, Ci, FK, Fe, Gr, GP, Gra, Grad, Ja, Jo, Kar, KP, Kis, KN, KS, Ko, Kos, Les, Law, LK, ML, ND, NB, Ry, SM, SL, Wi, Wie, Wik, WW, Wo, WSm, Wy, Za, Zab, Zam. Physalis alkekengi L. (1): Lu. Quercus rubra L. (31): BZ, DP, Gra, Iz, ID, Kar, KB, KP, Ke, Kor, Kro, Law, LK, LL, Lo, LoL, LW, NB, PD, Ro, Sa, Si, SWF, SM, SD, S1, Tr, Tu, WSm, Wy, Zam. Reynoutria japonica Houtt. (47): Ad, Bo, Bro, Ci, Da, DL, DP, FK, Go, Gra, Iz, ID, JSB, Ka, Kam, Kar, KB, KP, Ke, Ki, Kl, KS, Kor, Kw, La, Las, Les, Lo, LoL, LW, Mar, Mi, Mo, Pa, PL, SW, SD, Sl, Tru, Wi, Wie, Wier, WP, WSm, Za, Zab, Zam. Reynoutria sachalinensis (F. Schmidt) Nakai (3): Cz, La, SW. Rhus typhina L. (102): Al, Ad, Au, Bo, BM, Br, Bro, Brom, Brz, Bu, BZ, Ci, Cy, CD, CM, Cz, Da, De, Do, DL, DP, FB, FK, Go, GP, Grad, GN, Iz, JSB, JT, JM, Ja, Jo, Ka, Kam, KB, KP, Ke, Ki, K1, KN, KS, Ko, Kor, Kr, Kro, Kw, La, Las, Le, Les, LK, Lo, LoL, LW, Lu, Ma, ML, Mi, Mo, ND, NP, NS, NW, Pa, PD, PL, Ro, Ry, Sa, SP, Si, SW, SWF, SM, SD, StP, SL, Sl, TL, Tr, Tru, Tu, Wi, Wie, Wier, Wik, WS, WT, WW, Wo, WP, WM, WC, WSm, WWe, Wr, Wy, Za, Zab, Zam, Zi. Robinia pseudoaca$\underline{c i a}$ L. (88): Al, Au, Bi, Bo, BM, Bro, Bu, BZ, Ci, Cz, De, Do, DL, DP, FB, FK, Fe, Go, Gr, Gra, Grad, Ho, Iz, JSB, JT, Ja, Jo, Ka, Kam, Kar, KB, KP, Ke, Ki, Kis, Kl, KS, Ko, Kor, Kos, Kr, Kro, La, Las, Le, Les, Li, Law, LK, Lo, LW, Lu, Ma, Mi, ND, NB, NP, NS, PD, PK, Ry, Sa, SP, Si, SW, SM, SD, Sl, TL, Tr, Tru, Tu, Wi, Wier, Wik, WS, WT, WW, WM, WSm, WWe, Wr, Wy, Za, Zab, Zam, ZG, Zi. Rosa rugosa Thunb. (60): Bi, Bo, Brz, Bu, CM, Cz, FB, FK, Gr, GP, Gra, Grad, GN, Iz, JSB, Ja, Jo, Kam, Ke, Ki, Kl, Kos, Kw, La, Las, Le, 
Les, Li, Lo, LoL, LW, ML, Mar, Mo, ND, NB, Pa, PL, Ry, Sa, SP, Si, SW, SWF, SM, Sl, TL, Tr, Wi, Wie, Wik, WT, WW, WM, WSm, Wr, Wy, Za, Zab, Zam. Rudbeckia laciniata L. (60): Bi, Bro, Bu, Ci, Cy, CD, CM, Cz, Da, De, Do, Go, Gr, Gra, GN, JT, JM, Ja, Jo, Ka, Kam, KB, KP, Kis, Ko, Kos, Kro, La, Las, Le, Les, Li, Law, LL, LW, Lu, Mar, Mo, ND, NB, NS, NW, PD, PL, Ry, Si, SW, SD, TL, Tru, Wi, Wier, Wik, WT, WW, Wr, Wy, Za, Zab, Zam. Rumex confertus Willd. (32): Al, Ad, Au, Cy, De, Go, GN, Iz, JT, JM, KP, Ke, Ko, Kr, La, Las, Li, LW, Mi, Mo, NP, PD, PK, SP, SW, Sl, Wi, Wo, WP, Za, Zab, ZG. Sarothamnus scoparius (L.) W. D. J. Koch (12): Brom, Gra, Kis, Kos, Kr, Le, Les, LL, NB, Pa, Si, Sl. Setaria pumila (Poir.) Roem. \& Schult. (50): Al, Ad, Bi, Brz, Bu, Ci, CD, Cz, Da, FB, FK, Go, GP, Gra, GN, Ja, Jo, Kam, Ke, Kis, Kor, Kos, Las, Le, Les, Law, LL, Lo, Mar, Mi, ND, NB, NW, PK, PL, Ro, Ry, SP, Si, SW, SD, SL, TL, Tru, Wi, Wie, Wier, Wy, Za, Zam. Setaria viridis (L.) P. Beauv. (74): Al, Au, Bi, Bo, Bro, Brz, Bu, Ci, Cy, CD, Cz, Da, Do, DL, DP, FB, FK, Go, Gra, GN, Ho, Iz, ID, Ja, Jo, Kar, KB, KP, Kis, Kl, Kor, Kos, Kr, Kro, Kw, La, Li, Law, Lo, LW, Lu, Ma, Mar, Mi, Mo, ND, NB, NP, NW, Pa, PK, Ro, Ry, Sa, Si, SW, SWF, SM, SD, SL, Sl, Tr, Tru, Wier, Wik, WS, Wo, WC, WWe, Wr, Wy, Zab, Zam, ZG. Solidago canadensis L. (71): Al, Ad, Au, Bi, Bo, BM, Bro, Brom, CD, CM, Cz, De, Do, DP, FB, Fe, Go, GP, Gra, GN, Ho, JT, JM, Jo, Ka, Kam, Kar, KB, Ke, KS, Ko, Kor, Kr, Kro, Le, Les, Li, LK, Lo, ML, NB, NP, NS, NW, PD, PK, PL, Sa, SP, Si, SW, SWF, StP, SL, Sl, TL, Tr, Tu, Wie, Wier, Wik, WW, Wo, WM, WC, WSm, Wr, Wy, Za, Zab, Zi. Solidago gigantea Aiton (100): Al, Ad, Au, Bi, Bo, BM, Bro, Bu, Ci, Cy, CD, CM, Cz, Da, De, Do, DL, DP, FB, Fe, Go, Gr, GP, Gra, Grad, GN, Ho, Iz, ID, JSB, JT, JM, Ja, Jo, Ka, KB, KP, Kis, Kl, KN, KS, Ko, Kor, Kos, Kr, Kro, Kw, La, Las, Le, Les, Li, Law, LK, LL, Lo, LoL, ML, Mar, Mi, Mo, ND, NB, NP, NS, NW, Pa, PD, PL, Ro, Ry, Sa, SP, Si, SW, SWF, SM, StP, SL, Sl, Tr, Tru, Tu, Wie, Wik, WS, WT, WW, Wo, WM, WC, WSm, WWe, Wr, Wy, Za, Zab, Zam, ZG, Zi. Sorbaria sorbifolia (L.) A. Braun (2): NB, Sl. Spiraea chamaedryfolia L. emend. Jacq. (30): Ad, Cz, Do, Go, GP, Gra, GN, Iz, Ka, Kl, Ko, La, Las, Le, LW, ML, Mar, Mo, NW, PL, Sa, SD, SL, TL, Wier, WS, WW, WSm, Wy, Za. Symphoricarpos albus (L.) S. F. Blake (48): Au, Bi, Br, Brom, Brz, Ci, DL, DP, FK, Go, Gr, Gra, Iz, JSB, JT, Jo, Kar, Ke, Kis, K1, Kos, Kro, La, LL, Lo, LoL, LW, Lu, Ma, Mi, Mo, ND, NB, Pa, Ry, Sa, SD, Sl, TL, Tru, Wier, Wik, WT, WSm, Wr, Zab, Zam, ZG. Syringa vulgaris L. (97): Al, Ad, Au, Bi, Bo, BM, Br, Bro, Brom, Bu, BZ, Ci, Cy, De, Do, DL, DP, FB, Go, Gr, GP, Gra, Grad, GN, Ho, Iz, ID, JSB, JT, JM, Ja, Jo, Ka, Kam, Kar, KP, Ki, Kis, Kl, KN, KS, Ko, Kos, Kr, Kw, La, Las, Le, Les, Li, Law, LK, Lo, LoL, LW, Ma, ML, Mar, Mi, Mo, ND, NB, NP, Pa, PD, PK, PL, Ry, Sa, SP, Si, SW, SWF, SM, SD, StP, SL, Sl, TL, Tr, Tru, Tu, Wie, Wik, WS, WT, WW, Wo, WM, WC, WSm, WWe, Wr, Za, Zab, Zam, ZG. Veronica persica Poir. (29): Al, Bi, Brz, Bu, Ci, CM, Go, Gr, Gra, Ja, Jo, Kam, Kor, Kos, Kr, Law, ND, NB, NP, PK, Ro, Ry, Sa, SP, Si, SD, SL, Tru, Zam. Xanthium albinum (Widder) H. Scholz (2): Li, Zam. 